\title{
Zoledronik Asidin Meme Kanseri Alt Tiplerinde Terapötik Etkisinin Değerlendirilmesi
}

\section{Assessment of The Therapeutic Effects of Zoledronic Acid on Breast Cancer Subtypes}

\author{
Gamze Güney Eskiler ${ }^{1}$, Asuman Deveci Özkan ${ }^{1}$, Cemil Bilir $^{2}$, Süleyman Kaleli ${ }^{1}$ \\ ${ }^{1}$ Sakarya Üniversitesi, Tip Fakültesi, Tibbi Biyoloji Anabilim Dal, Sakarya, Türkiye \\ ${ }^{2}$ Sakarya Üniversitesi, Tip Fakültesi, Tibbi Onkoloji Bilim Dal, Sakarya, Türkiye \\ Yazısma Adresi / Correspondence: \\ Gamze Güney Eskiler \\ Sakarya Üniversitesi Tip Fakültesi Tıbbi Biyoloji AD, Korucuk Mahallesi Konuralp Bulvarı No:81/1 Korucuk Kampüsü, Adapazarı/Sakarya \\ T: +902642954308 E-mail: gamzeguney@sakarya.edu.tr \\ Geliş Tarihi / Received : 11.01.2019 Kabul Tarihi / Accepted : 25.01.2019
}

$\ddot{\mathrm{O} z}$

Amaç Meme kanseri kadınlarda en sık görülen ve farklı alt tiplere ayrılan heterojen bir kanser türüdür. Bu nedenle, meme kanseri alt tiplerine özgü tedavi yaklaşımları dikkat çekmektedir. Mevcut çalışmada, kemik metastazı görülen kanser tiplerinin tedavisinde klinikte kullanılan ve anti-proliferatif ve anti-metastatik etkiye sahip olduğu bilinen bir bifosfonat inhibitörü zoledronik asitin (ZOL)'ün, iki farklı meme kanseri alt tipinde [MCF-7 (luminal A) ve MDA-MB-231 (triple negatif)] ve insan göbek kordonu veni endotel hücrelerinde (HUVEC) terapötik etkisinin araştırılması amaçlanmıștır. ( Sakarya Tip Dergisi 2019, 9(1):92-102 )

Gerec ve ZOL’ün (10-100 $\mu \mathrm{M})$ sitotoksik ve apoptotik etkisi WST-1, Annexin V ve hücre siklusu analizleri ile belirlenmiștir. Ayrıca ZOL'ün, hücrelerde ve nukleusta neden olduğu

Yöntem morfolojik değişimler sırasıyla akridin oranj (AO) ve DAPI boyaması ile görüntülenmiştir.

Bulgular ZOLün MCF-7 hücrelerine göre, MDA-MB-231 hücrelerinde daha fazla anti-proliferatif etkiye ve erken ve geç apoptotik ölüme neden olduğu analiz edilmiştir (p<0.05). Özellikle 50 ve100 $\mathrm{M}$ ZOL uygulanan hücrelerde G0/G1 fazında hücre miktarının anlamlı bir șekilde arttığı saptanmıștır (p<0.05). Bunun yanı sıra, ZOL uygulanan MCF7 ve MDA-MB-231 hücrelerinde, hücre membran bütünlüğünde bozulma ve kromatin yoğunlașması gözlemlenmiștir. Ancak, yüksek konsantrasyonlarda ZOL’ün HUVEC hücrelerinde toksik etkiye neden olduğu belirlenmiștir.

Sonuç Sonuç olarak, ZOL’ün farklı meme kanseri alt tiplerinde potansiyel terapötik etkiye sahip olduğu belirlenmekle birlikte, MDA-MB-231 hücrelerinde, MCF-7 hücrelerine göre daha fazla sitotoksik etkiye ve apoptotik ölüme neden olduğu tespit edilmiştir. Ancak, ZOL’ün meme kanseri alt tipine bağlı olarak değișen terapötik etkisine neden olan moleküler mekanizmaların ve ideal uygulama protokolünün belirlenmesine yönelik detaylı çalıșmalara ihtiyaç bulunmaktadır.

Anahtar Meme kanseri; meme kanseri alt tipleri; zoledronik asit; apoptoz

Abstract

Objective Breast cancer is a heterogeneous type of cancer with many subtypes and is the most common cancer among women. It is noteworthy that breast cancer subtype-based treatment options have attracted great attention. In the present study, we aimed to investigate the therapeutic effect of a bisphosphonate inhibitor zoledronic acid (ZOL), which is a clinically used in the treatment of cancer types with bone metastases and has been found to exert anti-proliferative and anti-metastatic effects, on two different subtypes of breast cancer [MCF-7 (luminal A) and MDA-MB-23I (triple negative)] and human umbilical vein endothelial cell (HUVEC). (Sakarya Med J 2019, 9(1):92-102)

Materials and The cytotoxic and apoptotic effect of ZOL (10-100 uM) were determined by WST-1, Annexin V and cell cycle analysis. In addition, changes in cell morphology and nucleus after treatment with

Methods ZOL were observed by acridine orange (AO) and DAPI staining, respectively.

Results ZOL caused more anti-proliferative effect and early and late apoptotic death in MDA-MB-231 cells compared with MCF-7 cells ( $p<0.05)$. The cell population in G0/G1 phase was significantly

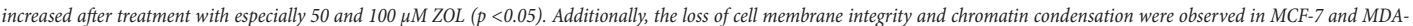
MB-231 cells treated with ZOL. However, ZOL had a toxic effect on HUVEC cells at higher concentrations.

Conclusion In conclusion, although ZOL has a potential therapeutic effect on different subtypes of breast cancer, ZOL causes more cytotoxic effects and apoptotic death in MDA-MB-23I cells than MCF-7 cells. However, further studies are needed to determine the molecular mechanisms underlying the therapeutic effect of ZOL depending on subtypes of breast cancer and the optimal schedule and dose of ZOL.

Key words Breast cancer; Breast cancer subtypes; Zoledronic acid; Apoptosis 


\section{GIIRIŞ}

Meme kanseri dünya genelinde akciğer kanserinden sonra ikinci sırada gelen ve kadınlarda en sık görülen kanser tipidir. ${ }^{1,2}$ Meme kanserinin genomik, epigenetik, transkripsiyonel ve proteomik analizler sonucunda farklı klinik, morfolojik, histopatolojik ve prognostik özelliklere sahip olduğu ve bu nedenle tedaviye farklı yanıt gösteren heterojen kompleks bir hastalık olarak belirtilmektedir. ${ }^{3,4}$ Dolayısıyla, meme kanserinin alt tipine özgü hedefli ilaçların geliştirilmesi ve/veya klinikte uygulanması, hastanın tedaviye yanıtında, prognozunda ve bireysel hedefli tedavi seçeneklerinin geliştirilmesinde büyük öneme sahiptir. ${ }^{5-8}$ Meme kanseri ile ilişkili ölüm nedenleri arasında diğer kanser tiplerine göre meme kanseri hücrelerinin başta akciğer, karaciğer ve kemik olmak üzere yüksek metastatik potansiyele sahip olmaları temel rol almaktadır., ${ }^{910}$ Kemik metastazı metastatik hücreler tarafından osteoklast temelli kemik rezorpsiyonunun uyarılmasını sağlayarak kemiklerde osteolize, kırılganlığa ve kırılmaya yatkınlığa neden olmaktadır. Zoledronik asidin (ZOL) yer aldığı bifosfonatlar osteklast temelli kemik rezorpsiyonu inhibitörleridir ve bu nedenle kemik hastalıkları, postmenopozal osteoporoz ve kemik metastazı görülen kanser tiplerinin tedavisinde klinikte kullanılmaktadır. Bifosfonatların ana hedefi osteoklastlar olmasına rağmen, son yıllarda yapılan ön-klinik ve klinik çalışmalarda bifosfonatların anti-kanser aktiviteleri üzerine odaklanılmaktadır. ${ }^{10-13}$

Azot içeren bifosfonatlardan biri olarak ZOL'ün farklı kanser tiplerinde anti-proliferatif, anti-metastatik ve anti-anyijogenik etkiye sahip olduğu literatür de belirtilmektedir. ${ }^{14-18}$ ZOL'ün meme kanseri tedavisinde etkisinin araştırıldığı ön-klinik ve klinik araştırmalar incelendiğinde, ZOL'ün meme kanseri alt tipine, uygulanan doz ve süresine bağlı olarak değişen terapötik etkisinin belirlendiği farklı sonuçlar mevcuttur. ${ }^{19-21}$ Ayrıca, in vitro çalışmalarda ZOL'ün meme kanseri hücrelerinde apoptotik ölüme neden olduğu belirlenmesine rağmen, ölüme neden olan moleküler mekanizmalar henüz tam olarak aydınlatılamamıştır. ${ }^{22,23}$
Bu kapsamda mevcut çalışmanın amacı, ZOL’ün iki farklı meme kanseri alt tipinde [MCF-7 (östrojen reseptörü pozitif $(\mathrm{ER}+)$, progesteron reseptörü pozifit $(\mathrm{PR}+)$, insan epidermal büyüme faktörü reseptörü 2 negatif (HER2-) ve MDA-MB-231 (ER-, PR-, HER2-)] uygulanan konsantrasyonuna ve süresine bağlı olarak bağlı değișen terapötik etkisinin araştırılmasıdır.

\section{GEREÇ VE YÖNTEMLER}

\section{Hücre Kültürï̈}

Mevcut çalışmada, bir in vitro araştırması olduğu için, hormon duyarlı meme kanseri hücre hattı olarak MCF-7 ve hormon duyarsız, triple negatif meme kanseri hücre hattı olarak MDA-MB-231 hücreleri kullanılmıştır. Bunun yanı sıra olarak insan göbek kordonu veni endotel hücresi (HUVEC) kontrol hücre hattı olarak kullanılmıştır. Hücreler ATCC (American Type Culture Collection, $\mathrm{ABD}$ )'den ticari olarak temin edilmiştir. MCF-7, MDAMB-231 ve HUVEC hücre hatlarının Dulbecco's Modified Eagle Media (DMEM, Sigma-Aldrich, ABD) besiyerine \%10 Fetal Sığır Serumu (FBS, Gibco, Invitrogen, ABD) ve $\% 1$ Penisilin-Streptomisin (Sigma-Aldrich St ABD) eklenerek $37^{\circ} \mathrm{C}$ 'de, \%95 nem ve $\% 5 \mathrm{CO} 2$ içeren etüv içerisinde kültüre edilmesi sağlanmıştır.

\section{Sitotoksisite Analizi}

ZOL (Novartis, İsviçre) $10 \mathrm{mM}$ stok solüsyon elde edilecek şekilde hazırlandıktan sonra deneyler gerçekleştirilinceye kadar alikotlanarak $-20^{\circ} \mathrm{C}^{\prime}$ de saklanmıştır. MCF-7, MDAMB-231 ve HUVEC hücreleri her bir kuyuya 2x104 hücre olacak şekilde 96 ’lı kuyucuklu kültür plakalarına ekildikten 24 saat sonra, hücrelere 10, 25, 50 ve $100 \mu \mathrm{M}$ ZOL eklenerek hücreler 24 ve 48 saat boyunca etüvde inkübe edilmiştir. Belirlenen inkübasyon sürelerinin sonunda, her bir kuyuya $10 \mu \mathrm{L}$ WST-1 (Proliferation Colorimetric Reagent WST-1, BioVision, ABD) reaktifi eklendikten sonra, 96’lı kuyucuklu kültür plakaları $37^{\circ} \mathrm{C}$ 'de 30 dakika boyunca karanlıkta inkübe edilmiştir. Son olarak, hücrelerin mikroplaka okuyucu (Allsheng, Çin) ile 450 nm'de absorbans değerleri okutularak hücre canlılığı analizi gerçekleştiril- 
miştir. Her bir deney 3 tekrarlı olarak gerçekleștirilmiştir.

\section{Annexin V Analizi}

MCF-7, MDA-MB-231 ve HUVEC hücrelerinde ZOL'ün apoptotik etkisi Muse Annexin V \& Dead Cell Assay (Millipore, Almanya) kullanılarak analiz edilmiştir. MCF-7, MDA-MB-231 ve HUVEC hücreleri 6 kuyulu plakalara 1 x 105 kuyu/hücre olarak ekildikten 24 saat sonra, 10, 25, 50 ve $100 \mu \mathrm{M}$ ZOL ile 48 saat boyunca inkübe edilmiştir. İnkübasyon sonunda, hücreler 5 dakika boyunca $2000 \mathrm{x}$ g'de santrifüj edilerek, iki kez soğuk fosfat tamponu (PBS) ile yıkanmıştır. Sonrasında, her bir deney grubu Annexin V \& Dead Cell Assay kiti ile boyanarak, oda sıcaklığında 30 dakika boyunca karanlıkta inkübe edildikten sonra Muse ${ }^{\varpi}$ Cell Analyzer (Millipore, Almanya) cihazı kullanılarak analiz edilmiştir.

\section{Hücre Siklusu Analizi}

ZOLün MCF-7, MDA-MB-231 ve HUVEC hücrelerinde hücre siklusu üzerindeki etkisini analiz etmek için Muse Cell Cycle Kit (Millipore, Almanya) kullanılmıştır. MCF-7, MDA-MB-231 ve HUVEC hücreleri 6 kuyucuklu plakalara 5 x $105 \mathrm{kuyu} /$ hücre olarak ekildikten 24 saat sonra, 10, 25, 50 ve $100 \mu \mathrm{M}$ ZA ile 48 saat boyunca inkübe edilmiştir. İnkübasyon sonrasında hücreler \%70 soğuk etil alkol ile fikse edilerek 3 saat boyunca $-20^{\circ} \mathrm{C}$ 'de bekletilmiştir. Fikse edilen hücreler soğuk PBS ile iki kez yıkanarak santrifüjlenmiştir ( $5 \mathrm{dk} / 2000 \mathrm{x}$ g). Sonrasında, toplanan hücreler 30 dakika boyunca karanlıkta Muse Cell Cycle Kit (Millipore, Almanya) ile inkübe edilerek, Muse ${ }^{\bowtie}$ Cell Analyzer (Millipore, Almanya) ile analiz edilmiştir.

\section{Akridin Oranj ve DAPI Boyama}

ZOL'ün MCF-7, MDA-MB-231 ve HUVEC hücrelerinde neden olduğu morfolojik değişimlerin görüntülenmesi için akridin oranj (AO) (Sigma-Aldrich, ABD) ve nukleus morfolojisindeki değişimlerin görüntülenmesi için DAPI (Sigma-Aldrich, ABD) boyaması gerçekleştirilmiştir. Hücreler 6 kuyucuklu plaka içerisinde her bir kuyuya 5 x 105 hücre olacak şekilde ekildikten 24 saat sonra, 10, 25, 50 ve
$100 \mu \mathrm{M}$ ZOL ile 48 saat boyunca inkübe edilmiştir. İnkübasyon sonrasında hücreler oda sıcaklığında 15 dakika boyunca \%4 paraformaldehid ile fikse edilerek karanlık koşullarda 30 dakika boyunca AO (100 mg/ml) veya 5 dakika boyunca DAPI ( $5 \mathrm{mg} / \mathrm{ml}$ ) ile boyanmış ve PBS ile üç kez yıkanmıştır. Son olarak, görüntüler EVOS FL Hücre Görüntüleme Sistemi (Thermo Fisher Scientific, Waltham, Massachusetts, ABD) yardımıyla elde edilmiştir.

\section{İstatistiksel Analiz}

İstatistiksel analiz için GraphPad Prism 6 (La Jolla, CA, ABD) programı kullanılmıştır. Bütün deneyler en az 3 tekrarlı gerçekleştirilmiştir. Elde edilen değerler ortalama \pm standart hata olarak ifade edilmiş olup, doza bağlı ölüm oranlarının, toplam apoptotik hücre ve hücre siklusundaki hücre miktarlarının karşılaştırılmasında Post Hoc (Tukey) tek yönlü varyans analizi (ANOVA) kullanılmıştır. ${ }^{*} \mathrm{p}<0.05$ istatistiksel olarak anlamlı kabul edilmiştir.

\section{BULGULAR}

\section{ZOL'ün Sitotoksik Etkisinin Belirlenmesi}

ZOL'ün MCF-7, MDA-MB-231 ve HUVEC hücre hatlarında sitotoksik etkisinin değerlendirilmesi için WST-1 analizi gerçekleştirilmiştir ve elde edilen bulgular Şekil 1'de özetlenmiştir. 24 ve 48 saat boyunca farklı konsantrasyonlarda ZOL uygulanan hücrelerde canlılık oranlarının doza ve zamana bağlı olarak anlamlı bir şekilde azaldığg belirlendi $(\mathrm{p}<0.05) .48$ saat boyunca $10 \mu \mathrm{M}$ ZOL uygulanan MCF-7 ve MDA-MB-231 hücrelerinde canlılık oranları sirası ile $\% 87,88 \pm 1,73$ ve $\% 82,47 \pm 1,73$ iken, $100 \mu \mathrm{M} Z \mathrm{ZOL}$ uygulandığında hücrelerde canlılık oranlarının anlamlı bir şekilde sirasıyla $\% 67,15 \pm 3,68$ ve $\% 29,05 \pm 3,11$ 'e azaldığ analiz edildi ( $\mathrm{p}<0.01) .48$ saat boyunca 10 ve $100 \mu \mathrm{M}$ ZOL uygulanan HUVEC hücrelerinde ise canlılık oranı sirası ile $\% 91,73 \pm 1,24$ ve $\% 63,75 \pm 2,50$ olarak belirlendi. Sonuç olarak, ZOL'ün MCF-7 hücrelerine göre, MDA-MB-231 hücrelerinde daha fazla anti-proliferatif etkiye neden olduğu belirlenmiştir. Ancak, yüksek konsantrasyonlarda ZOL'ün HUVEC hücrelerinde toksik etkiye sahip olduğu tespit edilmiştir. 
A

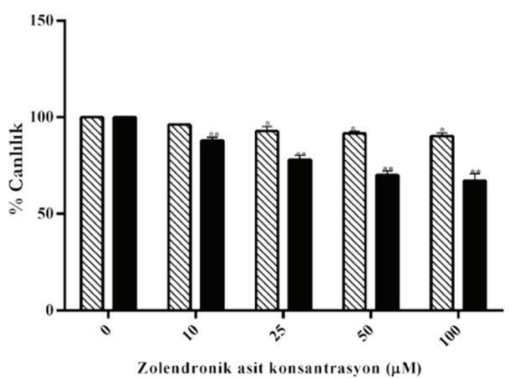

B
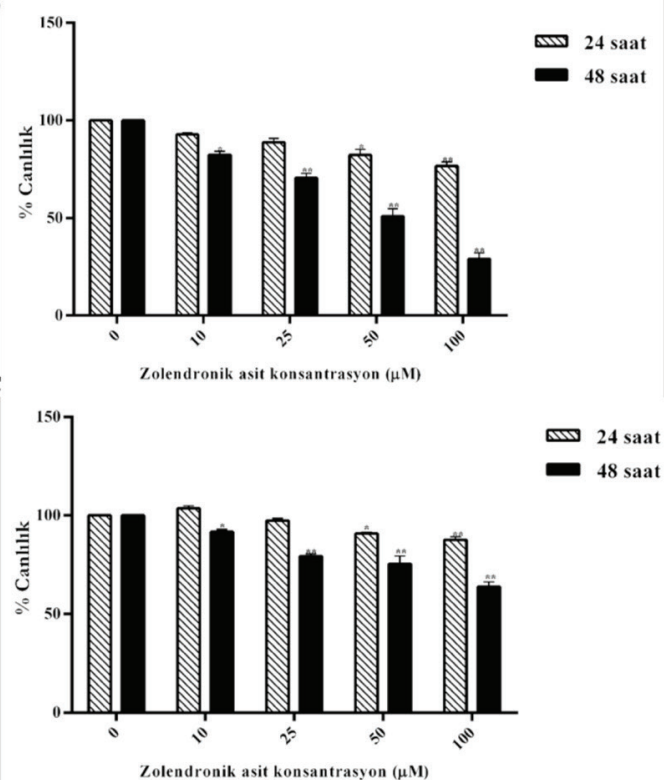

Şekil 1. ZOL'ün (A) MCF-7, (B) MDA-MB-231 ve (C) HUVEC hücrelerinde anti-proliferatif etkisinin belirlenmesi. Farklı konsantrasyonlarda ZOL (10, 25, 50 ve $100 \mu \mathrm{M})$ uygulanan hücrelerde 24 ve 48 saat için canlılık yüzdeleri kontrol grubu ile karşılaştırılarak istatistiksel olarak analiz edilmiştir $\left({ }^{*} \mathrm{p}<0.05,{ }^{* *} \mathrm{p}<0.01\right)$.

\section{ZOL'ün Apoptotik Etkisinin Belirlenmesi}

ZOL'ün MCF-7, MDA-MB-231 ve HUVEC hücrelerinde apoptotik etkisi incelendiğinde, uygulanan doza bağlı olarak özellikle toplam apoptoz yüzdelerinde anlamlı bir artış olduğu gözlemlenmiştir ( $\mathrm{p}<0.01$, Şekil 2). $10 \mu \mathrm{M}$ ve 100 $\mu \mathrm{M}$ ZOL'ün MCF-7 hücrelerinde apoptotik etkisi incelendiğinde, kontrol grubu $(00,00 \pm 1,34)$ ile karşılaştırıldığın$\mathrm{da}$, hücrelerde toplam apoptoz oranı sirasiyla $\% 8,82 \pm 0,66$ ve $\% 28,44 \pm 1,07$ iken, MDA-MB-231 hücrelerinde bu oranların sırasıyla kontrol gurubuna göre $(\% 5,61 \pm 0,78)$,
$2 a$
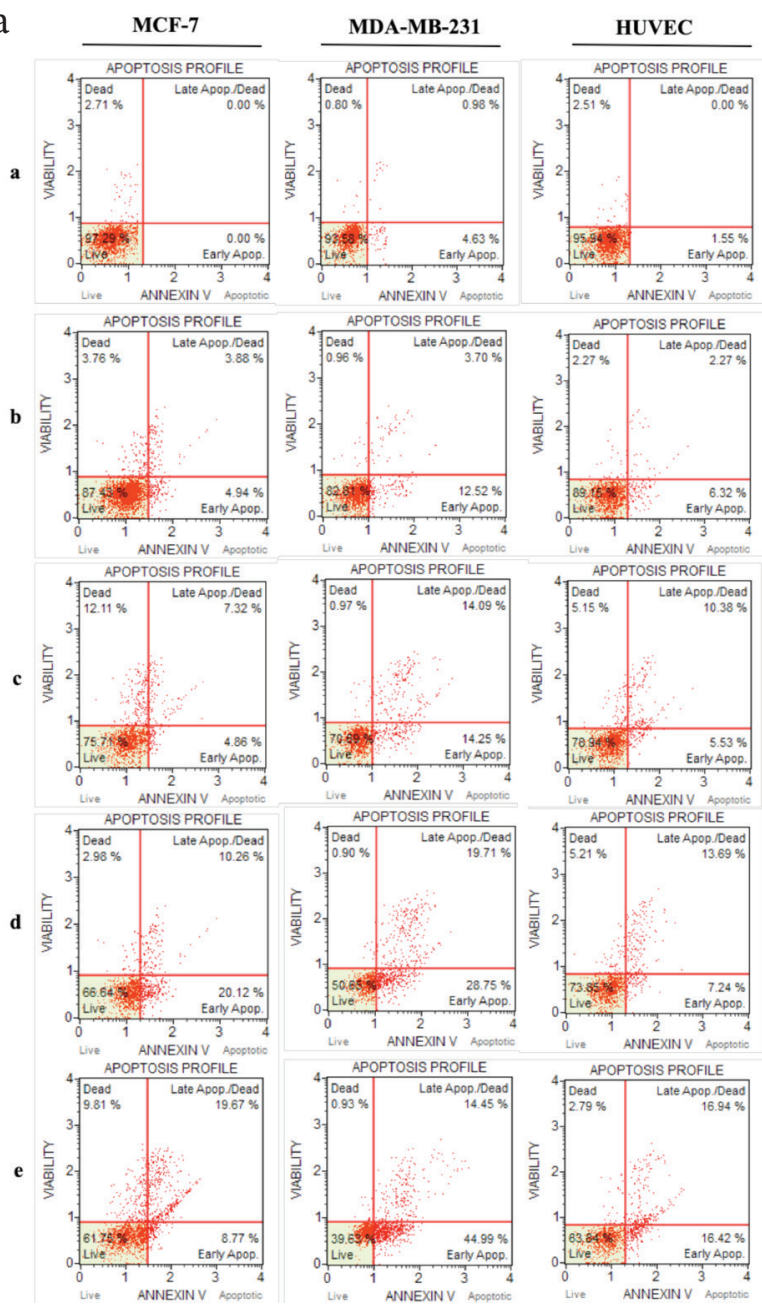

$2 b$

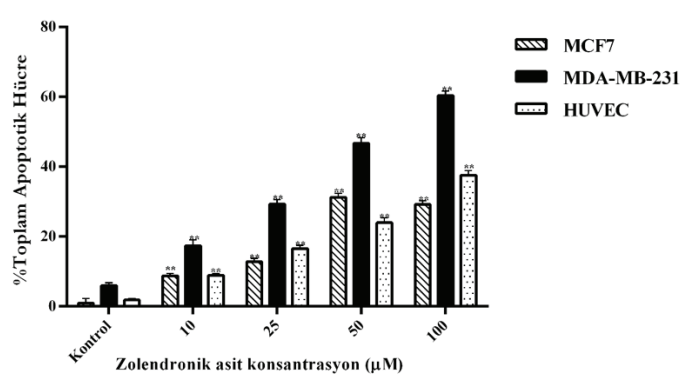

Şekil 2. 48 saat boyunca farklı konsantrasyonlarda ZOL uygulanan MCF-7, MDA-MB-231 ve HUVEC hücrelerinde apoptotik ölümün değerlendirilmesi. (2a) (a) Kontrol, (b) 10 $\mu \mathrm{M}$, (c) $25 \mu \mathrm{M}$, (d) $50 \mu \mathrm{M}$ ve (e) $100 \mu \mathrm{M}$ ZOL'ün hücrelerde apoptotik etkisi Annexin $\mathrm{V}$ analizi ile değerlendirilmiştir. (2b) ZOL'ün hücrelerde toplam apoptotik etkisi kontrol grubu ile karşılaştırılarak istatistiksel olarak analiz edilmiştir $\left({ }^{*} \mathrm{p}<0.05\right.$, $\left.{ }^{* *} \mathrm{p}<0.01\right)$. 
$\% 16,22 \pm 1,64$ ve $\% 59,44 \pm 1,27$ 'e arttı ̆̆ belirlendi $(\mathrm{p}<0.01)$. HUVEC hücrelerinde ise, kontrol grubu $(1,83 \pm 0,39)$ ile karşılaştırıldığında, $10 \mu \mathrm{M}$ ve $100 \mu \mathrm{M}$ ZOL uygulanması sonucunda, hücrelerde toplam apoptoz oranları sırasiyla $\% 8,92 \pm 0,47$ ve $\% 37,56 \pm 1,32$ olarak tespit edildi. Sonuç olarak, ZOL'ün hem MCF-7 hem de MDA-MB-231 hücrelerinde apoptotik ölüme neden olduğu ancak MDAMB-231 hücrelerinde MCF-7 hücrelerine göre daha fazla oranda erken ve geç apoptotik ölümde artışa neden olduğu analiz edilmiştir ve elde edilen bulgular WST-1 analizinden elde edilen sonuçlar ile paralellik göstermektedir.

\section{ZOL'ün Hücre Siklusu Üzerinde Etkisinin Belirlenmesi}

ZOL'ün MCF-7, MDA-MB-231 ve HUVEC hücrelerinde hücre siklusu üzerinde etkisinin belirlenmesi amacıyla hücre siklusu analizi gerçekleştirilmiş ve elde edilen bulgular Şekil 3'de özetlenmiştir. 48 saat boyunca $10 \mu \mathrm{M}$ ve $100 \mu \mathrm{M}$ ZOL uygulanan MCF-7 hücrelerinde kontrol grubu $(\% 71,30 \pm 0,92)$ ile karşılaştırıldığında G0/G1 fazında hücre miktarı sırası ile $\% 71,00 \pm 0,79$ ve $\% 84,10 \pm 0,64$ olarak belirlenmesine rağmen, MDA-MB-231 hücrelerinde kontrol gurubu $(\% 65,50 \pm 1,34)$ ile karşılaştırıldığında, G0/G1 fazında hücre miktarının sırası ile $\% 75,60 \pm 0,99$ ve $\% 90,70 \pm 0,21^{\prime} \mathrm{e}$ arttığ 1 analiz edildi $(\mathrm{p}<0.01)$. HUVEC hücrelerinde ise, kontrol grubu $(\% 71,10 \pm 1,41)$ ile karşılaşt1rildığında, $10 \mu \mathrm{M}$ ve $100 \mu \mathrm{M}$ ZOL uygulanan hücrelerde G0/G1 fazında hücre miktarının sırasıyla $\% 77,80 \pm 1,70$ ve $\% 84,20 \pm 1,56$ 'e arttığı belirlendi $(\mathrm{p}<0.01)$. Sonuç olarak, özellikle yüksek konsantrasyonlarda ZOL uygulanan hücrelerde G0/G1 fazında hücre miktarında anlamlı bir şekilde artış olduğu tespit edilmiştir.

\section{Hücre Morfolojisindeki Değişimlerin Görüntülenmesi}

Farklı konsantrasyonlarda ZOL'ün MCF-7, MDA-MB-231 ve HUVEC hücrelerinde neden olduğu morfolojik değişimler AO boyaması ile görüntülenmiştir (Şekil 4). MCF7, MDA-MB-231 ve HUVEC hücrelerinde ZOL'ün artan konsantrasyonuna bağlı olarak hücrelerde apoptotik ölümün arttığ1 görüntülendi. ZOL uygulanan MCF-7 ve MDA-MB-231 hücrelerinde kontrol grupları ile karşılaş- tırıldığında, hücre membran bütünlüğünde bozulma, kromatin yoğunlaşması ve hücre ve/veya sitoplazmik küçülmeler olduğu gözlemlendi.
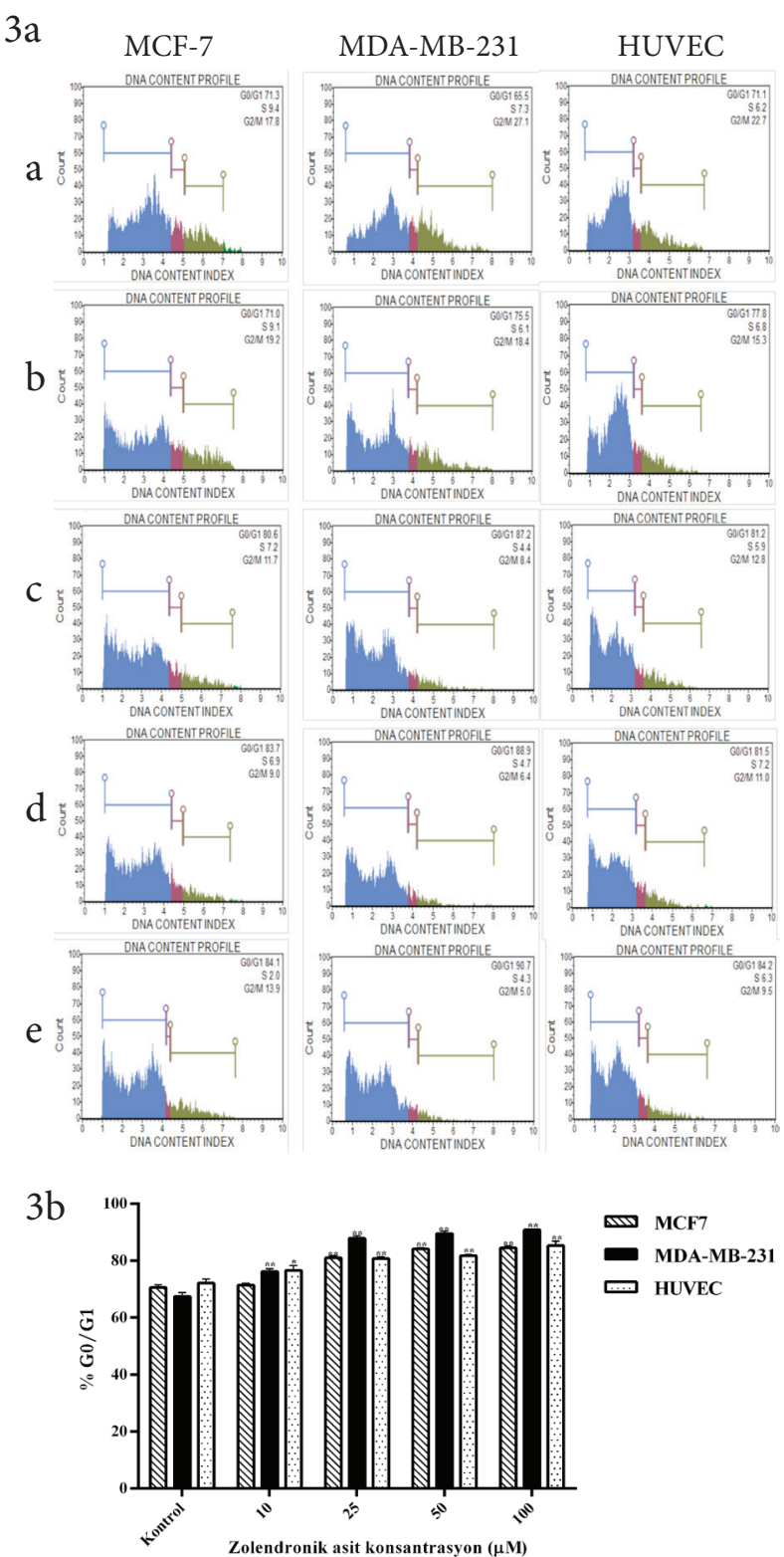

Şekil 3. 48 saat boyunca farklı konsantrasyonlarda ZOLün MCF-7, MDA-MB-231 ve HUVEC hücrelerinde hücre siklusu üzerinde etkisinin değerlendirilmesi. (3a) (a) Kontrol, (b) $10 \mu \mathrm{M}$, (c) $25 \mu \mathrm{M}$, (d) $50 \mu \mathrm{M}$ ve (e) $100 \mu \mathrm{M}$ ZOLün hücrelerde etkisi hücre siklusu analizi ile değerlendirilmiştir. (3b) ZOL'ün neden olduğu G0/G1 fazında hücre miktarında artış kontrol grubu ile karşılaştırılarak istatistiksel olarak analiz edilmiştir $\left({ }^{*} \mathrm{p}<0.05,{ }^{* *} \mathrm{p}<0.01\right)$. 

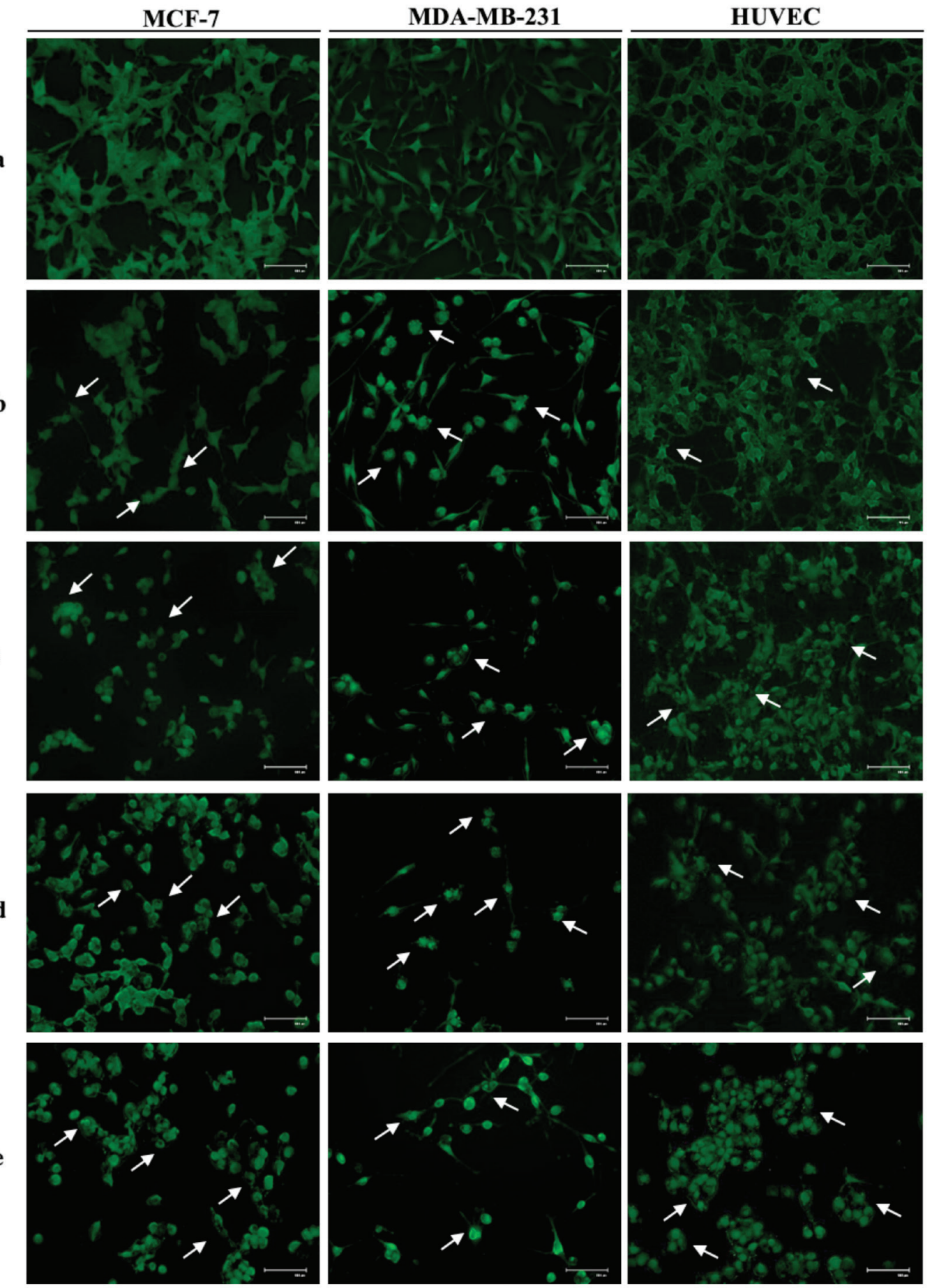

Şekil 4. Farklı konsantrasyonlarda ZOL’ün MCF-7, MDA-MB-231 ve HUVEC hücrelerinde neden olduğu morfolojik değişimlerin AO boyaması ile görüntülenmesi. (a) Kontrol, (b) $10 \mu \mathrm{M}$, (c) $25 \mu \mathrm{M}$, (d) $50 \mu \mathrm{M}$ ve (e) $100 \mu \mathrm{M}$ ZOL. 
MCF-7

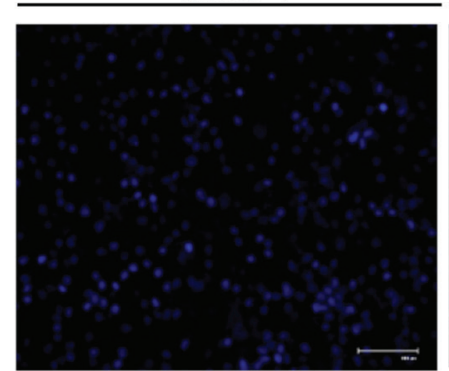

b
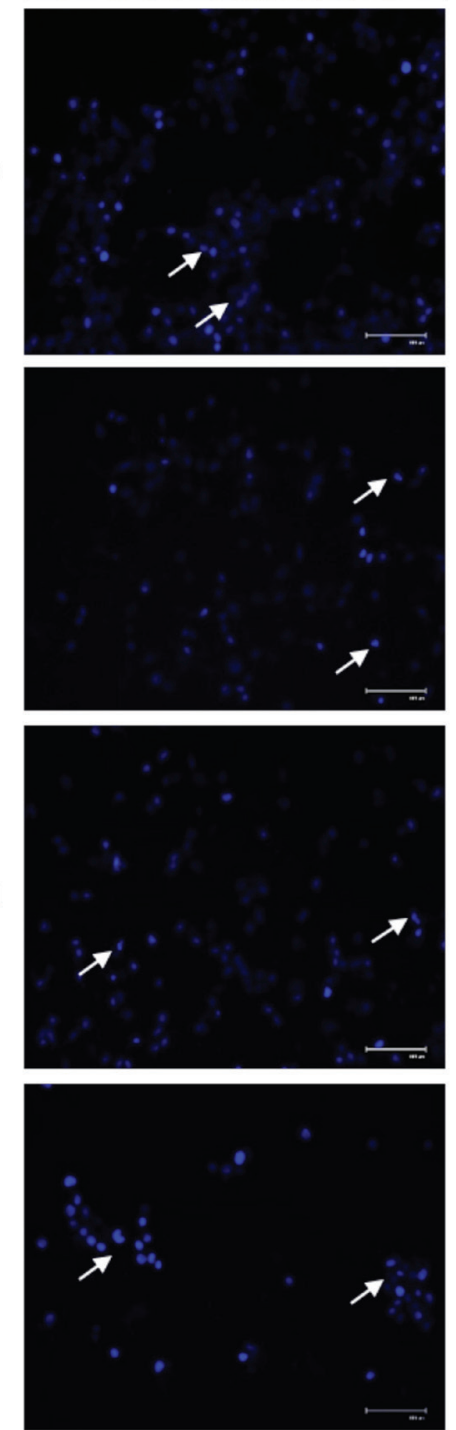

MDA-MB-231
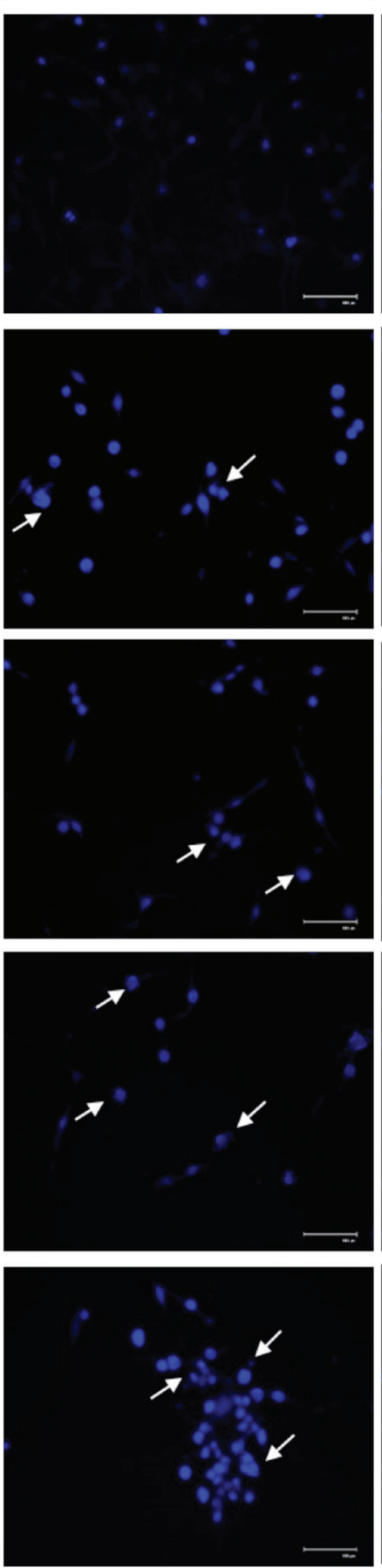

HUVEC
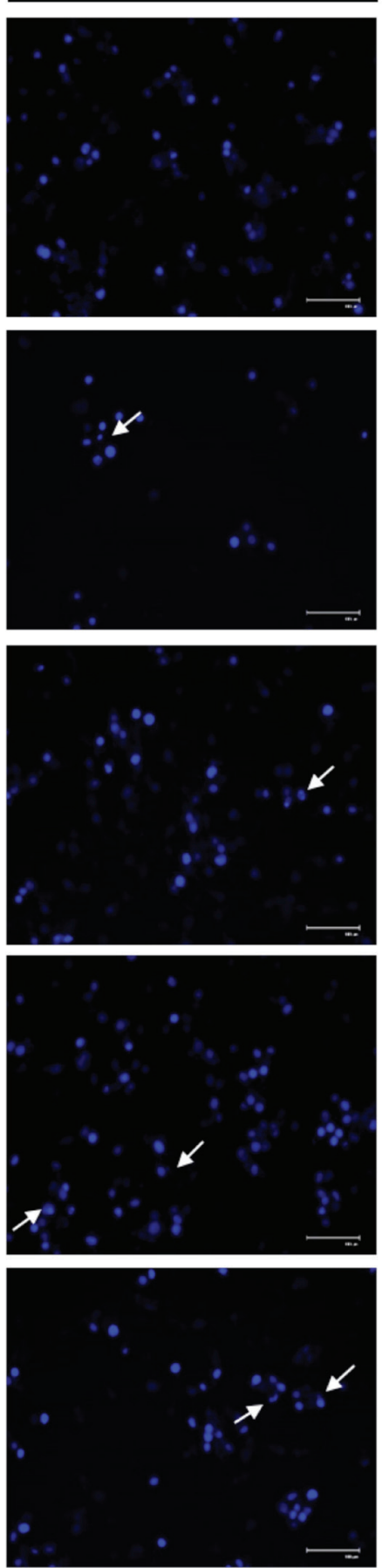

Şekil 5. Farklı konsantrasyonlarda ZOL uygulanan MCF-7, MDA-MB-231 ve HUVEC hücrelerinde nükleus morfolojilerinin DAPI boyaması ile görüntülenmesi. (a) Kontrol, (b) $10 \mu \mathrm{M}$, (c) $25 \mu \mathrm{M}$, (d) $50 \mu \mathrm{M}$ ve (e) $100 \mu \mathrm{M}$ ZOL 
Ayrıca, özellikle 50 ve $100 \mu \mathrm{M}$ ZOL uygulanan MDAMB-231 hücrelerinde apoptotik cisimcikler ve nükleer fragmentasyon belirlenmesine rağmen, MCF-7 hücrelerinde apoptotik hücrelerin yanı sıra nekrotik hücreler de tespit edildi. HUVEC hücrelerinde ise $10 \mu \mathrm{M}$ ZOL uygulanmasından itibaren hücrelerin genel morfolojik yapısını kaybettiği ve apoptotik cisimcikler ve nükleer hasar belirlendi.

Ayrica belirlenen konsantrasyonlarda (10, 25, 50 ve 100 $\mu \mathrm{M})$ ZOL uygulanan MCF-7, MDA-MB-231 ve HUVEC hücrelerinde nükleus morfolojileri DAPI boyaması ile görüntülenmiştir (Şekil 5). ZOLün artan konsantrasyonuna bağlı olarak hücrelerde kromatin yoğunlaşması ve nükleus fragmentasyonu olan apoptotik hücreler gözlemlendi. Sonuç olarak, ZOL'ün MDA-MB-231 hücrelerinde MCF-7 hücrelerine göre daha fazla apoptotik ölüme neden olduğu ancak yüksek konsantrasyonlarda HUVEC hücrelerinde de toksik etkiye sahip olduğu belirlenmiştir.

\section{TARTIŞMA}

Mevcut çalışmada, ZOL'ün farklı meme kanseri alt tiplerinde kontrol hücre hattı ile karşılaştırmalı olarak potansiyel terapötik etkiye sahip olduğu belirlenmiştir. Sonuç olarak, ZOL'ün MDA-MB-231 hücrelerinde MCF-7 hücrelerine göre daha fazla sitotoksik etkiye ve apoptotik ölüme neden olmasıyla birlikte yüksek konsantrasyonlar da kontrol hücrelerinde toksik etkisi tespit edilmiştir.

ZOL potansiyel üçüncü nesil bir bifosfonat inhibitörüdür ve son yıllarda meme kanseri hastalarında klinikte yaygın olarak kullanılmaktadır. Ön-klinik çalışmalarda ZOL’ün kanser hücrelerinde doğrudan ve dolaylı olarak anti-proliferatif etkisi in vitro ve in vivo belirlenmiştir. ZOL'ün farklı kanser tiplerinde doğrudan etkisi uygulanan doza ve zamana bağlı olarak hücrelerde neden olduğu sitotoksik etkiye ve apoptotik ölüme dayanmaktadır. Dolaylı etkisi ise, kanser hücrelerinin proliferasyonu için uygun ortamı sağlayan kemik mikroçevresinde etkisine bağlıdır. ${ }^{16,21,24}$

Klinik faz çalışmalarında (ABCSG12, AZURE, Z-Fast,
ZO-Fast, NATAN, SUCCESS, SWOG 0307, ZEUS, RADAR, STAMPEDE Study 2419) ise, adjuvan tedavi olarak ZOL'ün meme, prostat ve küçük hücreli olmayan akciğer kanseri hastalarında genel olarak hastalıksız sağ kalım süresinde etkili olduğuna dair sonuçlar mevcuttur. ${ }^{16,24-26}$ Örneğin, ABCSG12 klinik denemesinde, ZOL'ün premenopozal I/II evre meme kanseri hastalarında endokrin tedavi ile birlikte uygulandığında hastalıksız sağ kalım süresinde artış sağladığı belirtilmektedir. Ancak, AZURE klinik denemesinde standart tedaviye ek olarak ZOL uygulanmasinın premenopozal II/III evre meme kanseri hastalarında hastalıksız sağ kalım süresinde etkili olmadığ belirlenmiştir. Sonuç olarak, ABCSG12 ve AZURE klinik denemelerinde ZOL'ün adjuvan kemoterapi olarak uygulama protokollerinin ve farklı hasta kriterlerin olmasından dolayı farklılıklar mevcuttur. Bu nedenle, ZOL'ün kanser tedavisinde ideal kullanımı hasta alt gruplarının, ZOL'ün farmakokinetik özellikleri ile uyumlu olarak anti-tümör mekanizmalarının ve ideal kombin tedavi olarak uygulanacağı kemoterapik ajanların belirlenmesine bağlıdır. ${ }^{26-28}$ Bunun yanı sıra, ZOL'ün anti-tümör etkisinin maksimum seviyede olması için, osteoporoz ve kemik metastazı olan hastalarda önerilen uygulama protokolünün optimize edilmesine de gerek duyulmaktadır. ${ }^{29,30}$

Farkl1 konsantrasyonlarda ve uygulama sürelerinde (24168 saat) ZOL'ün (6.25-100 $\mu \mathrm{M})$, farklı kanser tiplerinde (meme, prostat, mesane ve akciğer kanseri, hepatoselüler karsinoma ve multipl miyelom) terapötik etkisinin araşt1rıldığ 1 çeşitli çalışmalar mevcuttur. ${ }^{16-18}$ Ancak, kanser tipi ve özelliklerine bağlı olarak ZOL'ün etkin konsantrasyon ve uygulama süresinin değiştiği ve kontrol hücrelerinde etkisinin belirlendiği çalışma sayısının literatürde sınırlı olmasından dolayı, mevcut çalışmada iki farklı alt tipte meme kanserinde ZOL'ün potansiyel terapötik etkisi araştırılmıştır.

Literatürde belirlendiği gibi ${ }^{20,21}$, mevcut çalışmada farklı konsantrasyonlarda ZOL'ün $(10,25,50$ ve $100 \mu \mathrm{M}) 24$ ve 48 saat boyunca MCF-7, MDA-MB-231 ve HUVEC hüc- 
relerinde sitotoksik etkisi araştırılmış ve ZOL'ün uygulanan doza ve zamana bağlı olarak MCF-7 ve MDA-MB-231 hücrelerinde hücre proliferasyonunu anlamlı bir şekilde azalttığı tespit edilmiştir. Bunun yanı sıra, özellikle 48 saat boyunca $100 \mu \mathrm{M}$ ZOL uygulanan HUVEC hücrelerinde ZOL'ün toksik etkisi ve hücrelerde apoptotik ölüme ve G0/ G1 fazında artışa neden olduğu analiz edilmiştir. Ayrıca, MDA-MB-231 hücrelerinin MCF-7 hücrelerine göre ZOL'a karşı daha duyarlı olduğu belirlenmiştir. Ancak, Senaratne ve ark. ${ }^{19}$ çalışmalarında MCF-7 ve MDA-MB-231 hücrelerinde bifosfonatların benzer bir şekilde etki gösterdiğini tespit etmiştir. Diğer yandan, Toni ve ark. (2012), MCF-7 (ER+,PR+, HER2-), SK-BR-3 (ER-, PR-,HER2+), MDAMB-231 ve BRC-230 (ER-, PR-, HER2-) hücrelerinde 12.5, 25 ve $50 \mu \mathrm{M}$ ZOL'ün 24, 48, 72, 96, 144 ve 168 saat boyunca etkisini araştırdıklarında çalışmalarında, triple negatif meme kanseri hücrelerinin (MDA-MB-231 ve BRC-230) hormon reseptör $(\mathrm{HR})+(\mathrm{MCF}-7)$ ve HER2+ (SK-BR-3) meme kanseri hücrelerine göre ZOL'e karşı daha duyarlı olduğu belirtilmektedir. Ayrıca, KRAS ve BRAF mutasyonu taşıyan MDA-MB-231 hücrelerinin, BRAF, KRAS ve HRAS değişimi olmayan BRC-230 hücrelerine göre ZOL’e karşı daha duyarlı olduğu belirlenmiştir. MCF-7 ve SK-BR-3 hücrelerinin ZOL’e karşı daha az duyarlı olmasının ise sırasıyla kaspaz-3'ün eksprese olmaması ve yüksek HER2 ekspresyonu sonucu RAS yolağının aktivitesinden kaynaklanabileceği belirtilmiştir. Ayrıca, ZOL’ün farklı alt tipte meme kanseri hücrelerinde G0/G1 fazında hücre miktarında artışa ve apoptotik ölüme neden olduğu ve bu ölümün triple negatif meme kanseri hücrelerinde RAS ekspresyonda ( $10 \mathrm{~kat})$ azalmaya neden olduğu belirlenmiştir. ${ }^{21}$ Wilson ve ark. ${ }^{31} 48$ saat boyunca $50 \mu \mathrm{M}$ ZOL uygulanan MDA-MB-231, MDA-MB-436, T47D ve MCF-7 hücrelerinde tripan mavi boyaması sonucunda, ZOLün triple negatif meme kanseri hücrelerinde (MDA-MB-231, MDA-MB-436) anti-proliferatif etkiye sahip olduğunu ancak, T47D ve MCF-7 hücrelerinde canlılık oranlarında ZOL'ün anlamlı bir azalmaya neden olmadığını belirtmişlerdir.
ZOL'ün meme ve prostat kanseri hücrelerinde apoptotik etkisinin araştırıldığı çalışmalar mevcuttur. Örneğin, Jagdev ve ark. ${ }^{32}, 72$ saat boyunca $0.1,1,10$ ve $100 \mu \mathrm{M} Z \mathrm{ZOL}$ uygulanan MCF-7 ve MDA-MB-231 hücrelerinde canlılık oranlarının anlamlı bir şekilde azaldığını ve ZOL'ün hücrelerde apoptotik ölüme neden olduğunu belirtmişlerdir. Ancak, $0.1 \mu \mathrm{M}$ ve $1 \mu \mathrm{M}$ ZOLün MCF-7 hücrelerinde apoptotik ölüm de anlamlı bir artışa neden olmazken, $10 \mu \mathrm{M}$ ZOL'ün hücrelerde 4 kattan daha fazla apoptotik ölüme neden olduğunu analiz etmişlerdir. Ayrıca, 0.1, 1,10 $\mu \mathrm{M}$ ZOL'ün MDA-MB-231 hücrelerinde daha az oranda apoptotik ölüme neden olmasına rağmen, $100 \mu \mathrm{M}$ ZOL uygulanan hücrelerde 15 kat apoptotik ölümde artış olduğunu tespit etmişlerdir. Diğer yandan Lan ve ark., 24, 48 ve 72 saat boyunca $0.1,1,10,50$ ve $100 \mu \mathrm{M}$ ZOLün MCF-7 ve MDA-MB-231 hücrelerinde etkisini inceledikleri çalışmalarında, özellikle 72 saat boyunca 50 ve $100 \mu \mathrm{M}$ ZOL'ün MCF-7 ve MDA-MB-231 hücrelerinde canlılık oranlarında anlamlı bir azalmaya ve özellikle $50 \mu \mathrm{M}$ ZOL'ün hücrelerde G0/G1 ve S fazında artışa ve apoptotik ölüme neden olduğunu belirtmişlerdir. ${ }^{10}$ Gschwantler-Kaulic ve ark. ${ }^{33}$ postmenapozal meme kanseri hastalarında ZA'nın hastalıksız sağ kalım üzerinde etkisini belirlemek için yaptıkları çalışmalarında, hormonal çevreyi taklit etmek için estradiol ile birlikte ZOLün MCF-7, T47D ve MDAMB-231 hücrelerinde etkisini belirlemişlerdir. Sonuç olarak, 6 gün boyunca 2.25, 6.25 ve $10.25 \mu \mathrm{M}$ ZOL uygulanan hücrelerde ZOLün hücrelerde G0/G1 ve S fazında hücre miktarında artışa ve apoptotik ölüme neden olduğunu ve ZOL'ün hormon durumundan bağımsız olarak anti-kanser etkiye sahip olduğunu tespit etmişlerdir. Ayrıca, ZOL'ün anti-kanser etkisinin MDA-MB-231 hücrelerinde estradiolden bağımsız bir şekilde gerçekleştiğini ancak MCF-7 ve T47D hücrelerinde estradiolün ZOL'ün anti-proliferatif ve pro-apoptotik etkisini önemli derecede azalttığını belirtmişlerdir. Prostat kanserinde ise, Mani ve ark.ZOL'ün (5, $10,25,50$ ve $100 \mu \mathrm{M}) 24,48$ ve 72 saat boyunca PC-3, DU145 ve LNCaP prostat kanseri hücrelerinde anti-proliferatif ve proapoptotik etkiye sahip olduğunu belirlemişlerdir ${ }^{34}$ (100 $\mu$ M ZOL'ün etki düzeyi; PC-3 > DU-145 > LNCaP). 
Ayrıca $100 \mu \mathrm{M}$ ZOL'ün PC-3 ve DU-145 hücrelerinde erken apoptoza neden olmasina rağmen, LNCaP hücrelerinde geç apoptoza neden olduğunu tespit etmişlerdir. Mevcut çalışmada, farklı konsantrasyonlarda ZOL'ün MCF-7, MDA-MB-231 ve HUVEC hücrelerinde apoptotik etkisi hem kantitatif hem de kalitatif olarak analiz edilmiştir. Sonuç olarak, ZOL'ün MDA-MB-231 hücrelerinde MCF-7 hücrelerine göre daha fazla oranda G0/G1 fazında hücre miktarına ve apoptotik ölüme neden olduğu belirlenmiştir. Ayrıca, apoptoz ile ilişkili karakteristik değişimler ve nükleus morfolojileri de görüntülenerek elde edilen veriler desteklenmiştir. Ancak literatür de ZOL'ün meme kanserinde farklı konsantrasyonlarda ve uygulama sürelerinde etkisinin araştırılmasından dolayı 10,19-21,31-33, ideal uygulama protokolünün (doz ve uygulama süresinin) ve hücrelerde apoptotik ölüme yol açmasına neden olan moleküler mekanizmaların belirlenmesine yönelik çalışmalara ihtiyaç duyulmaktadır.

\section{SONUÇ}

Mevcut çalışmada farklı konsantrasyonlarda ZOL'ün farklı alt tiplerde meme kanseri ve kontrol hücrelerinde etkisinin değerlendirilmesi ile literatüre katkı sağlanması amaçlanmıştır. Sonuç olarak ZOL'ün triple negatif meme kanserinde daha etkin olmasıyla birlikte kontrol hücrelerinde toksik etkisi belirlenmiştir. Ancak, ZOL'ün apoptotik etkisine neden olan moleküler mekanizmaların aydınlatılmasına ve ideal uygulama protokolünün (etkin konsantrasyonu ve uygulama süresi) belirlenmesine yönelik detaylı çalışmalara ihtiyaç bulunmaktadır. 
Sakarya Tip Dergisi 2019;9(1):92-102

GÜNEY ve Ark. Zoledronik Asidin Meme Kanseri Alt Tiplerinde Terapötik Etkisinin Değerlendirilmesi

\section{Kaynaklar}

1. Fitzmaurice C, Allen C, Barber RM, Barregard L, Bhutta ZA, Brenner H, et al. Global, regional, and national cancer incidence, mortality, years of life lost, years lived with disability, and disability-adjusted life-years for 32 cancer groups, 1990 to 2015: a systematic analysis for the global burden of disease study. JAMA oncology 2017; 3(4):524-548.

2. Bray F, Ferlay J, Soerjomataram I, Siegel RL, Torre LA, Jemal A. Global cancer statistics 2018: GLOBOCAN estimates of incidence and mortality worldwide for 36 cancers in 185 countries. CA Cancer J Clin 2018; 68(6):394-424.

3. Heiser LM, Sadanandam A, Kuo WL, Benz SC, Goldstein TC, Ng S, et al. Subtype and pathway specific responses to anticancer compounds in breast cancer. Proc Natl Acad Sci USA 2012; 109:2724-2729.

4. Sonnenblick A, Fumagalli D, Sotiriou C, Piccart M. Is the differentiation into molecular subtypes of breast cancer important for staging, local and systemic therapy, and follow up? Cancer Treat Rev 2014; 40:1089-1095.

5. Sharp A, Harper-wynne C. Treatment of advanced breast cancer (ABC): The expanding landscape of targeted therapies. J cancer Biol Res 2014; 2:1-5.

6. Weigelt B, Geyer FC, Reis-Filho JS. Histological types of breast cancer: How special are they? Mol Oncol 2010; 4:192-208.

7. Eroglu A, Çiçek E. Meme kanserinde moleküler alt tiplere göre cerrahi tedavi yaklaşımları. Yeni Tip Dergisi 2014; 31(2): 83-87.

8. Eliyatkin N, Yalcin E, Zengel B, Aktaș S, Vardar E. Molecular Classification of Breast Carcinoma: From Traditional, Old-Fashioned Way to A New Age, and A New Way. J Breast Heal 2015; 11:59-66.

9. Nguyen DX, Bos PD, Massague J. Metastasis: From dissemination to organ-specific colonization. Nat Rev Cancer 2009; 9:274-284.

10. Lan YC, Chang CL, Sung MT, Yin PH, Hsu CC, Wang KC, et al. Zoledronic acid-induced cytotoxicity through endoplasmic reticulum stress triggered REDD1-mTOR pathway in breast cancer cells. Anticancer Res 2013; 33(9):3807-3814.

11. Winter MC, Holen I, Coleman RE. Exploring the antitumour activity of bisphosphonates in early breast cancer. Cancer Treat Rev 2008; 34:453-475.

12. McClung M, Harris ST, Miller PD, Bauer DC, Davison KS, Dian L, et al. Bisphosphonate therapy for osteoporosis: benefits, risks, and drug holiday. Am J Med 2013; 126:13-20.

13. Delmas PD. Treatment of postmenopausal osteoporosis. Lancet 2002; 359:2018-2026.

14. Neville-Webbe HL, Coleman RE. Bisphosphonates and RANK ligand inhibitors for the treatment and prevention of metastatic bone disease. Eur J Cancer 2010; 46:1211-1222.

15. Bosch-Barrera J, Merajver SD, Menendez JA, Van PC. Direct antitumour activity of zoledronic acid: preclinical and clinical data. Clin Transl Oncol 2011; 13:148-155.

16. Guise TA. Antitumor effects of bisphosphonates: promising preclinical evidence. Cancer Treat Rev 2008; 34 Suppl 1:19-24.

17. Green J, Lipton A. Anticancer properties of zoledronic acid. Cancer Invest 2010; 28:944-957.

18. Zekri J, Mansour M, Karim SM. The anti-tumour effects of zoledronic acid. J bone oncol 2014; 3(1):25-35.

19. Senaratne SG, Pirianov G, Mansi JL, Arnett TR, Colston KW. Bisphosphonates induce apoptosis in human breast cancer cell lines. Br J Cancer 2000; 82(8):1459-1468.
20. Busch M, Rave-Frank M, Hille A, Duhmke E. Influence of clodronate on breast cancer cells in vitro. Eur J Med Res 1998; 3(9):427-431.

21. Ibrahim T, Mercatali L, Sacanna E, Tesei A, Carloni S, Ulivi P, et al. Inhibition of breast cancer cell proliferation in repeated and non-repeated treatment with zoledronic acid. Cancer Cell Int 2012; 12(1):48.

22. Almubarak H, Jones A, Chaisuparat R, Zhang M, Meiller TF, Scheper MA. Zoledronic acid directly suppresses cell proliferation and induces apoptosis in highly tumorigenic prostate and breast cancers. J Carcinog 2011; 10: 2 .

23. Senaratne SG, Colston KW. Direct effects of bisphosphonates on breast cancer cells. Breast Cancer Res 2012; 4:18-23.

24. Santini D, Virzi V, Fratto ME, Bertoldo F, Sabbatini R, Berardi R, et al. Can we consider zoledronic acid a new antitumor agent? Recent evidence in clinical setting. Curr Cancer Drug Targets 2010; 10(1):46-54.

25. Coleman R, Cameron D, Dodwell D, Bell R, Wilson C, Rathbone E, et al. Adjuvant zoledronic acid in patients with early breast cancer: final efficacy analysis of the AZURE (BIG 01/04) randomised open-label phase 3 trial. The lancet oncology 2014; 15(9): 997-1006.

26. Steinman RA, Brufsky AM, Oesterreich S.Zoledronic acid effectiveness against breast cancer metastases-a role for estrogen in the microenvironment?. Breast Cancer Res 2012; 14(5): 213.

27. Gnant M, Mlineritsch B, Stoeger H, Luschin-Ebengreuth G, Heck D, Menzel C, et al. Adjuvant endocrine therapy plus zoledronic acid in premenopausal women with early-stage breast cancer: 62-month followup from the ABCSG-12 randomised trial. Lancet Oncol 2011; 12:631-641.

28. Coleman RE, Marshall H, Cameron D, Dodwell D, Burkinshaw R, Keane M, et al. Breast-cancer adjuvant therapy with zoledronic acid. N Engl J Med 2011; 365:1396-1405.

29. Hershman DL, McMahon DJ, Crew KD, Cremers S, Irani D, Cucchiara G, et al. Zoledronic acid prevents bone loss in premenopausal women undergoing adjuvant chemotherapy for early-stage breast cancer. J Clin Oncol 2008; 26(29):4739-4745.

30. Zhao X, Xu X, Guo L, Ragaz J, Guo H, Wu J, et al. Biomarker alterations with metronomic use of low-dose zoledronic acid for breast cancer patients with bone metastases and potential clinical significance. Breast Cancer Res Treat 2010; 124(3):733-743.

31. Wilson C, Ottewell, P, Coleman RE, Holen I. The differential anti-tumour effects of zoledronic acid in breast cancer-evidence for a role of the activin signaling pathway. BMC cancer 2015; 15(1):55.

32. Jagdev SP, Coleman RE, Shipman CM, Rostami-H A, Croucher PI. The bisphosphonate, zoledronic acid, induces apoptosis of breast cancer cells: evidence for synergy with paclitaxel. Br J Cancer 2001; 84(8):1126.

33. Gschwantler-Kaulich D, Weingartshofer S, Grunt TW, Mairhofer M, Tan Y, Gamper J, et al. Estradiol impairs the antiproliferative and proapoptotic effect of Zoledronic acid in hormone sensitive breast cancer cells in vitro. PloS one 2017; 12(9): 0185566.

34. Mani J, Vallo S, Barth K, Makarević J, Juengel E, Bartsch G, et al. Zoledronic acid influences growth, migration and invasive activity of prostate cancer cells in vitro. Prostate Cancer Prostatic Dis 2012; 15(3):250. 